\title{
Protection objectives in Polish urban nature reserves as a challenge for their management
}

\author{
Maciej Wasilewski, Barbara Szulczewska
}

\begin{abstract}
157 nature reserves are situated in different parts of the spatial structure of Polish towns and cities. They were established at different times and often for different reasons than the nature reserves located outside Polish cities. Due to their location, urban reserves are very frequently used similarly to other green open spaces. The aim of this paper is to identify the main protection objectives of nature reserves located in towns and cities in order to find out to what extent their inevitable recreational use results in management problems. In order to identify the reserves' protection objectives and rules of recreational accessibility, a number of documents were examined: 111 designation acts (our analysis was limited to reserves located entirely within city or town borders), 35 management plans and 48 other regional ordinances. The research resulted in the following findings: a complicated and unclear formal situation of many surveyed reserves entails management problems, particularly in terms of their accessibility and recreational use. In theory, the current legal regulations allow for the introduction of rules concerning the recreational use of reserves and setting up of necessary facilities. However, in practice, this possibility is underused. It seems that nature reserves located in towns and cities require special attention, otherwise some of them will lose their natural values. The concept of the urban nature reserve should be considered as a solution.
\end{abstract}

\section{Introduction}

Nature reserves, along with national parks, belong to the group of the most valuable nature areas in Poland and because of that are among the most protected. Whereas none of the national parks are located within city borders (only the Kampinoski National Park is situated on the edge of the city of Warsaw), there are 157 nature reserves in different parts of the spatial structure of Polish towns and cities. They were established at different times and often for different reasons than the nature reserves located outside Polish cities. According to the categories developed by the International Union for Conservation of Nature (IUCN), all the Polish nature reserves should be classified as Habitat/Species Management Areas - category IV [Radziejowski 2011]. This category encompasses areas aiming to protect particular species or habitats where management reflects this priority. One of the other important protection objectives is providing areas where urban residents may obtain regular contact with nature [IUCN].

It should be emphasized that the legal framework for the establishment of nature reserves is described in the Polish Nature Protection Act 2004 (Ustawa z dnia 16 kwietnia 2004 r. o ochronie przyrody) (with amendments) and there are no special rules and procedures for reserves located in cities or towns. This creates certain management problems since many such reserves serve not only as areas dedicated to the protection of natural heritage, biodiversity, 
landscape, etc., but also as recreational areas [Bistuła-Prószyński 2003, Grabowska 2014, Malinowska, Szumacher 2013, Szulczewska 2002].

The Nature Protection Act 2004 indicates activities which are not allowed in nature reserves. These include not only activities that could undoubtedly threaten natural values, such as hunting, plant devastation, changes in water resources or relief, the use of chemicals or car traffic. Also included is a ban on cycling and walking which de facto precludes people from visiting reserves. However, many of leisure and recreation activities, e.g. walking, cycling, skiing, swimming, hiking, horse riding, picnicking or fishing can be partially allowed - in indicated areas - by the Regional Directorates for Environmental Protection as regulations included in management plans or in regional ordinances.

Currently, on the basis of green infrastructure concept [Ahern 2007, Giedych, et al. 2014, Mell, et al. 2013, Szulczewska 2009], one should redefine the role of nature reserves located in towns and cities so as to take into account not only the protection of natural heritage but also their meaning to the public. Therefore, the aim of this paper is to identify the main protection objectives of nature reserves located in towns and cities in order to find out to what extent their inevitable recreational use (one of the main functions of green spaces in cities) would create management problems.

\section{Materials and methods}

The research encompassed nature reserves located in Polish towns and cities. Urban nature reserves in Poland were identified according to official data about the locations and borders of cities and the boundaries of all the Polish reserves. ${ }^{1}$ Next, out of 157 reserves located in towns and cities, 111 were selected for further research. These are situated entirely within city borders (Fig. 1).

The main protection objectives in the chosen reserves were identified according to official data from the Regional Directorates for Environmental Protection. Three main types of documents were analyzed: designation acts, ${ }^{2}$ management plans $^{3}$ and regional ordinances containing basic information about reserves, including protection objectives. ${ }^{4}$ The data was supplemented with official information published on the websites of Regional Directorates for Environmental Protection. The information about the objectives was not interpreted, but taken directly from the source.

\footnotetext{
${ }^{1}$ Data from, respectively, the Geodesy and Cartography Documentation Centre (Centralny Ośrodek Dokumentacji Geodezyjnej i Kartograficznej) and the General Directorate for Environmental Protection (Generalna Dyrekcja Ochrony Środowiska)

2 Zarządzenia o powołaniu rezerwatów

3 Plany ochrony

${ }^{4}$ Zarządzenia Regionalnej Dyrekcji Ochrony Środowiska (RDOŚ) zawierające podstawowe informacje o rezerwatach, w tym cele ochrony.
} 
Fig. 1. Number of nature reserves located entirely within borders of Polish cities and towns and their location on the map of Poland

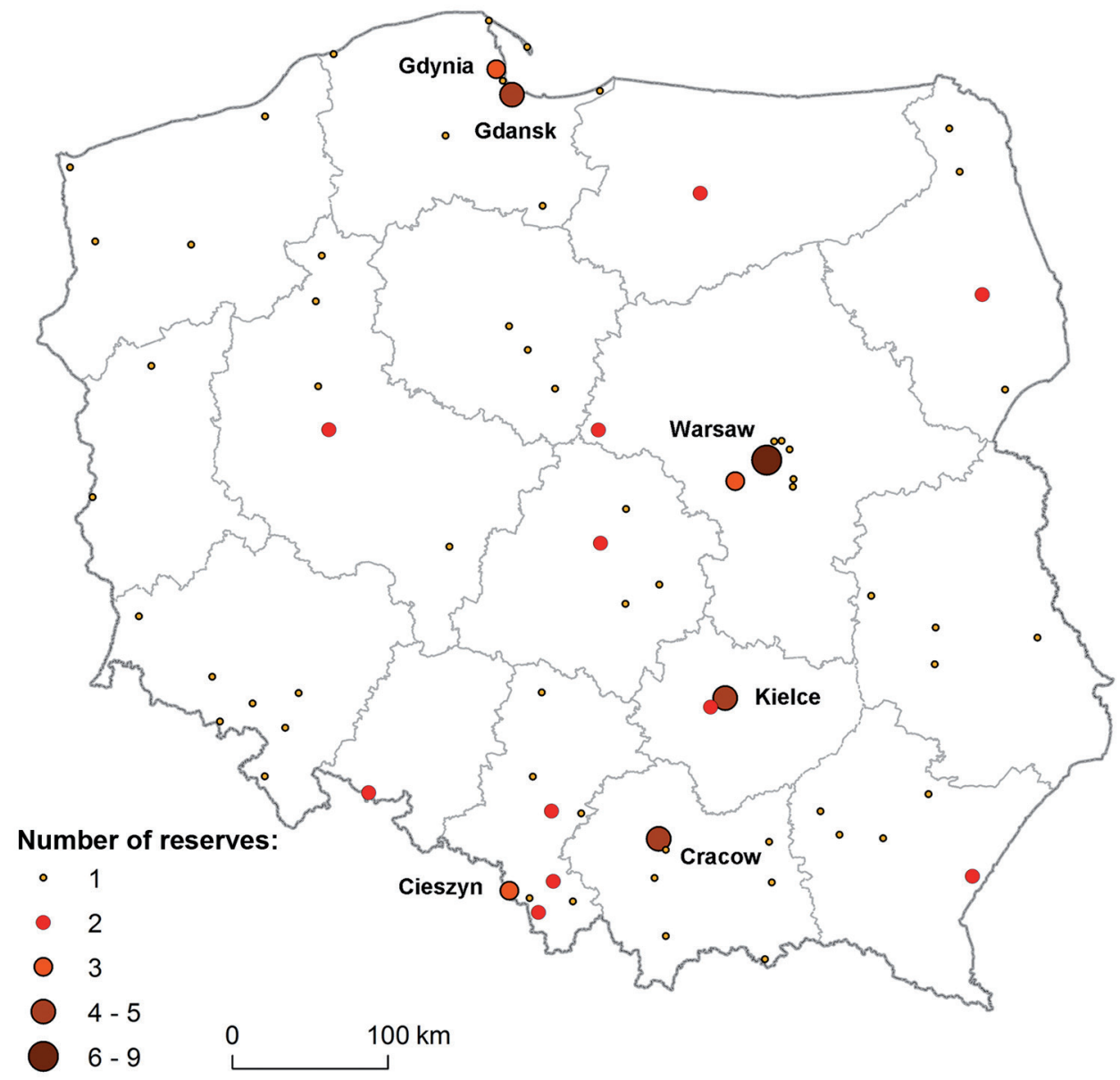

The protection objectives were divided into the following categories:
a) forest,
b) trees,
c) flora and fungi,
d) peatlands,
e) fauna,
f) features of geological interest,
g) surface water,
h) landscape,
i) cultural values. 
The division of the types of the objectives is presented in Table 1 along with examples.

Table 1. Division of protection objectives by type in the analyzed urban nature reserves

\begin{tabular}{|c|c|}
\hline $\begin{array}{l}\text { Types of protection objective } \\
\text { used in the research }\end{array}$ & $\begin{array}{l}\text { Examples of specific protection objectives derived from } \\
\text { analyzed documents }\end{array}$ \\
\hline Forest & forests of high natural values; forested areas; forest succession \\
\hline Trees & $\begin{array}{l}\text { relic habitat spots for certain tree species; habitat spots for rare tree } \\
\text { species; tree species important for natural forest character; tree } \\
\text { species at the border of their natural range; natural monuments; } \\
\text { picturesque tree shapes; }\end{array}$ \\
\hline Flora and fungi & $\begin{array}{l}\text { plant communities (other than forests); halophytes; xerothermic } \\
\text { grasslands; meadows; heathlands, forests' understory; fungi; }\end{array}$ \\
\hline Peatlands & $\begin{array}{l}\text { various stadiums of peatlands: bogs, fens, poor fens; swamps; } \\
\text { marshes }\end{array}$ \\
\hline Fauna & $\begin{array}{l}\text { certain species of mammals, birds, fish, insects and other animals } \\
\text { as well as their habitats; breeding areas of animals; }\end{array}$ \\
\hline Surface water & $\begin{array}{l}\text { water bodies, e.g. lakes; old river beds; rivers, streams and their } \\
\text { fragments; karst fensters }\end{array}$ \\
\hline Features of geological interest & $\begin{array}{l}\text { various geological features, e.g. hills, eskers, sand dunes; } \\
\text { topographical relief, moraine plateaus; rocks; rock exposures; } \\
\text { geological processes; river valleys; caves; underground mineral } \\
\text { deposits; soils; minerals; sediments; fossils }\end{array}$ \\
\hline Landscape & $\begin{array}{l}\text { picturesque geological landscapes; picturesque water landscapes; } \\
\text { landscape values of forests; unique landscapes; meteor craters }\end{array}$ \\
\hline Cultural values & $\begin{array}{l}\text { places of pagan worship; cultural values of forests; ruins of historic } \\
\text { buildings; historical values of forests; traces of deposit exploitation } \\
\text { in the past; historic graveyards; places of national heritage }\end{array}$ \\
\hline
\end{tabular}

According to the Nature Protection Act 2004, the Regional Directorate for Environmental Protection should specify the category, type and subtype of each reserve. The whole classification is regulated by the Decree of the Minister of the Environment from 2005. Reserves are divided into: (I) categories (e.g. forest, water, flora, etc.), (IIa) types and subtypes referring to a dominant subject of protection and (IIb) types and subtypes referring to a dominant ecosystem. This information (available so far for 80 out of 111 studied reserves) was a supplementary source for the division of protection objectives by the authors.

\footnotetext{
${ }^{5}$ Rozporzadzenie Ministra Środowiska z dn. 30 marca 2005 r. w sprawie rodzajów, typów i podtypów rezerwatów przyrody
} 
The sum of identified protection objectives helped to assess the reserves' landscape diversification and therefore, to some extent, their attractiveness to visitors.

Next, the accessibility of the surveyed reserves to the public was analyzed, that is which of them provide leisure and recreational services. The accessibility was identified according to the official regulations in regional law and management plans and then juxtaposed with the diversification of protection objectives in individual reserves

\section{Results}

In total the following numbers of official documents were examined: 111 designation acts, 35 management plans and 48 other regional ordinances.

\section{The main protection objectives}

Information about protection objectives was gathered for 111 Polish urban nature reserves located entirely within city boundaries. Figure 2 presents the number of nature reserves (and their share in the total) according to type of protection objectives. According to the collected data the most frequent objective of protection is the forest which is a feature preserved in 80 reserves $(72.1 \%$ of all the analyzed protected sites). It is then followed by flora -53 reserves $(47.7 \%)$, features of geological interest - $34(30.6 \%)$, landscape - $30(27.0 \%)$ and fauna - 26 $(23.4 \%)$. The protection objectives which appeared less frequently are trees $-19(17.1 \%)$, peat bogs - $15(13.5 \%)$ and surface water - 15 (13.5\%). The fewest of the analyzed reserves were established to protect cultural values. There are 13 reserves with this objective which constitutes $11.7 \%$ of all the investigated cases.

\section{Fig. 2. Protection objectives in the Polish urban nature reserves} (a number of nature reserves is shown in brackets)

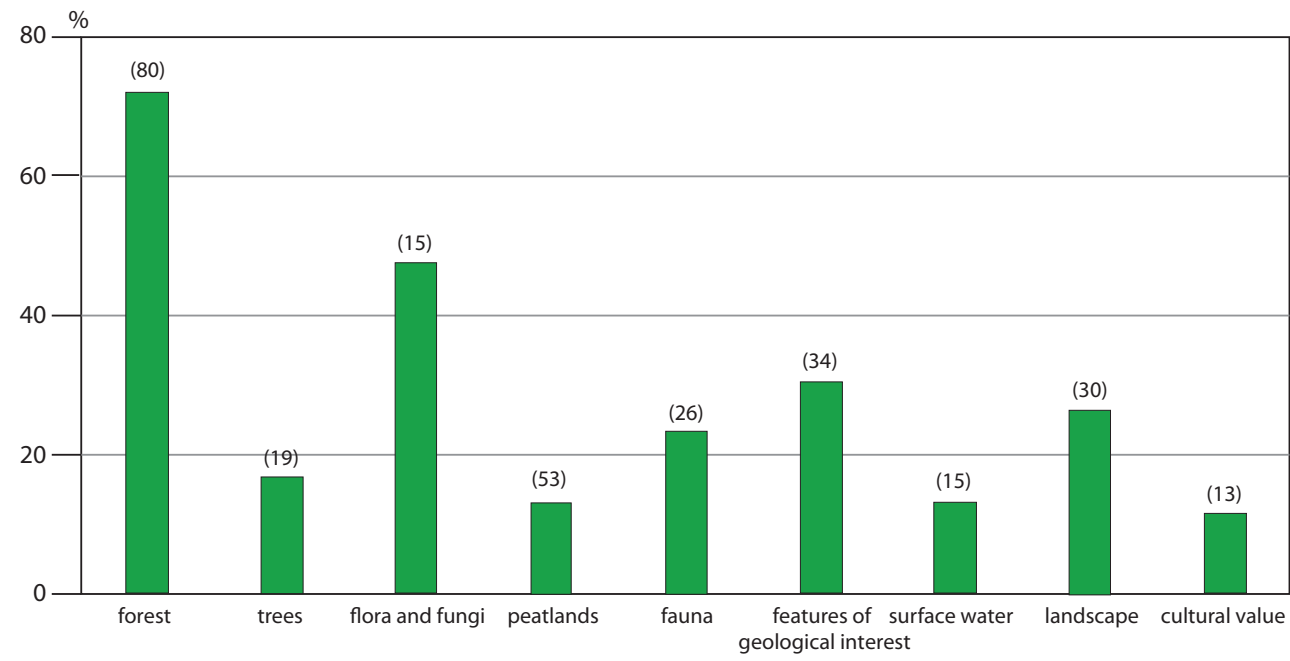




\section{Diversification of protection objectives}

Figure 3 presents the number of nature reserves (and their share in the total) according to the number of protection objectives. The median number of specified protection objectives per nature reserve is 2.59 ( $\min .1$, max. 9). In the largest number of the analyzed reserves $39(35.1 \%)$ - two protection objectives were established. Within this group, forests appears the most frequently - in 30 cases $(76.9 \%)$, and the most common combinations are with trees $-10(25.6 \%)$ and flora $-9(23.1 \%)$. A substantial part of the investigated areas -28 sites $(25.2 \%)$ - constitute nature reserves with only one specified protection objective. This is most frequently the forest, found in 14 out of 28 such examples. It is followed by flora, identified in 8 reserves. A smaller number of nature reserves have more than 2 assigned protection objectives. 18 reserves (16.2\%) aim to preserve 3 different aspects and 13 were established with 4 protection objectives in mind (11.7\%). 5 or more protection objectives were found in a few reserves with the highest diversification and landscape variety. 5 various objectives are to be found in 6 (5.4\%) of the analyzed reserves: Horowe Bagno in Marki, Mosty Kalińskie in Zielonka, Nad Białką in Głuchołazy, Przełomy pod Książem koło Wałbrzycha in Wałbrzych, Skarpa Ursynowska in Warsaw and Szwajcaria Ropczycka in Ropczyce. There are also 6 areas (5.4\%) with 6 different objectives: Biesak-Białogon in Kielce, Kępa Redłowska in Gdynia, Jaskinia Raj in Chęciny, Morysin in Warsaw and Niebieskie Źródła in Tomaszów Mazowiecki. Karczówka nature reserve, located in Kielce, is the only one with 7 different protection objectives. The following values are preserved in this area: the forest, old pine trees, flora, fauna, features of geological interest, landscape and cultural values. A larger number of objectives results in a higher attractiveness for visitors, since such nature reserves offer more possibilities of diverse leisure and recreational use.

\section{Fig. 3. Diversification of protection objectives in Polish urban nature reserves} (the number of nature reserves is shown in brackets)

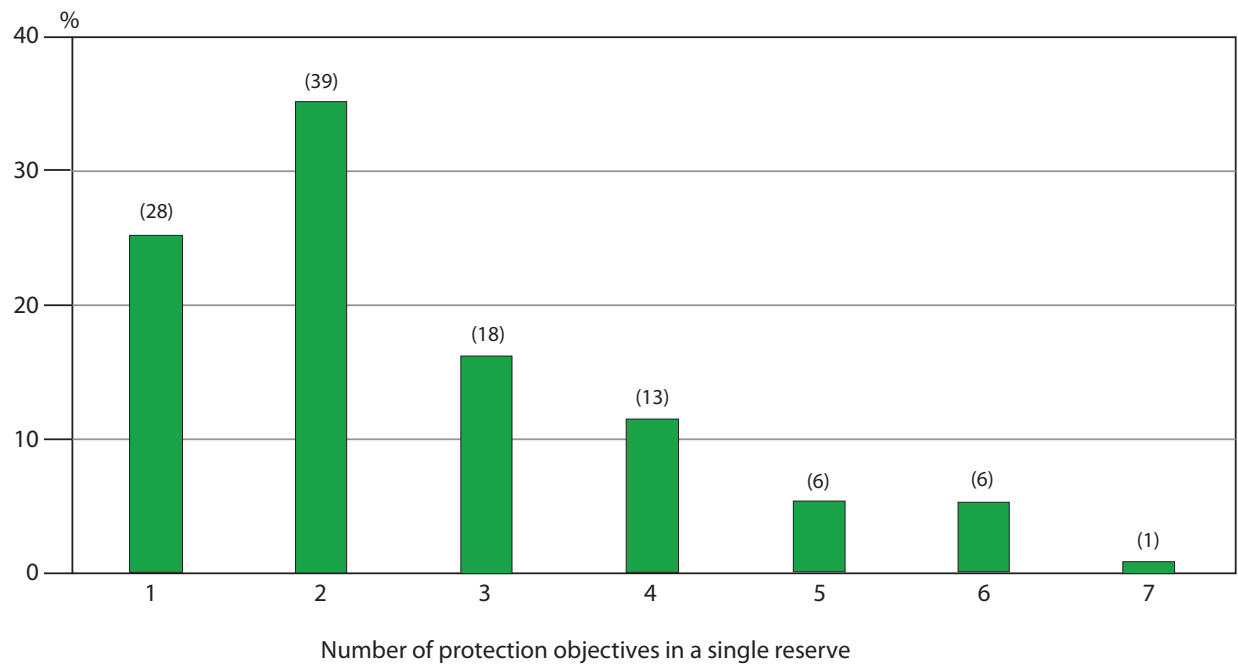




\section{Accessibility and recreational use}

Although most of the investigated nature reserves are visited by people and are used regularly for recreation (there are only a few examples of reserves without any tourist facilities, e.g. Bielica in Koszalin, Kozie Brody in Jastrowie, Wyspa Sołtyski in Ińsko or Zdroje in Szczecin), formal access to these protected areas - according to the law - has to be defined in documents published by the Regional Directorates for Environmental Protection. Altogether, 47 out of the 111 analyzed reserves (42.3\%) are legally accessible for public use. In 34 cases is regulated through regional ordinances, in 13 reserves through management plans. 3 of the studied nature reserves allow limited access to visitors: Groty Kryształowe in Wieliczka, Jaskinia Raj in Chęciny and Las Natoliński in Warsaw. In these areas open access and mass tourism are not allowed, they are available only for scientific and educational purposes. In Groty Kryształowe nature reserve, where underground salt crystals are preserved, access also requires consent from its manager - Zarząd Kopalni Wieliczka S.A. Only registered groups with a guide are allowed inside, in the period from 15th October to 15th April. A visit to Jaskinia Raj, which protects valuable caves with unique minerals, is also possible only for organized groups with a guide. The number of tourists as well as the opening hours are limited. Las Natoliński, unlike the 2 previous reserves, protects mainly a forest. Its accessibility, however, is also limited, mainly due to the high natural value of the woodland and numerous old monumental trees. The reserve is open only for small organized groups with a guide. However, due to changes in the management plan in 2016 and a lack of new necessary regulations, access to trails and paths in the reserve is not allowed. The rest of the analyzed reserves 64 (nearly 58\%) - do not have any regulations that enable legal access. Recreational use of

Fig. 4. Historical monuments in Las Natoliński nature reserve in Warsaw

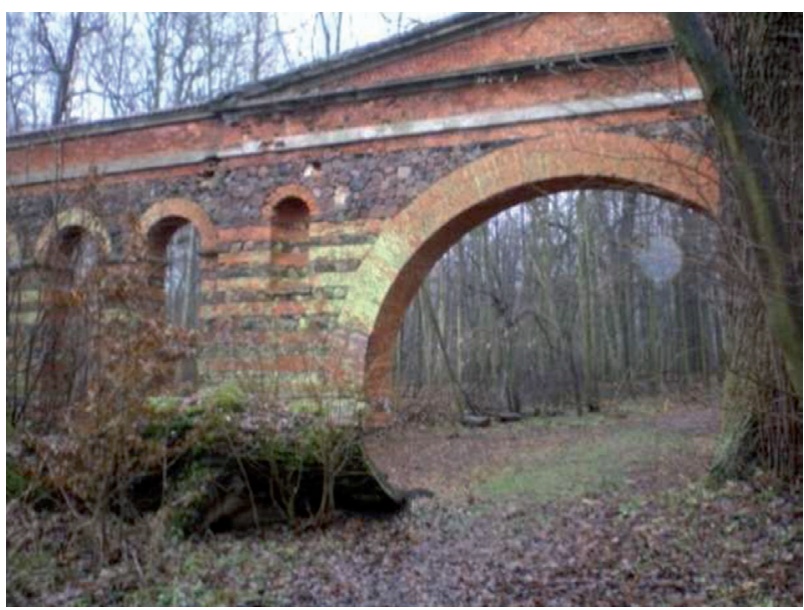
the protected areas is therefore formally forbidden. 45 out of the 47 nature reserves that are formally open for public use have arranged walking paths. The only 2 exceptions are: Las Natoliński - described above - and Góra Ślęża in Sobótka. In the first one areas around historical monuments are open to visitors (Fig. 4), in the latter one places for bonfires are indicated. However, an ordinance allowing pedestrian movement is still missing in both reserves.

Photo: Wasilewski M. 2008 
Fig. 5. Outdoor gym in Las Kabacki im. Stefana Starzyńskiego nature reserve in Warsaw

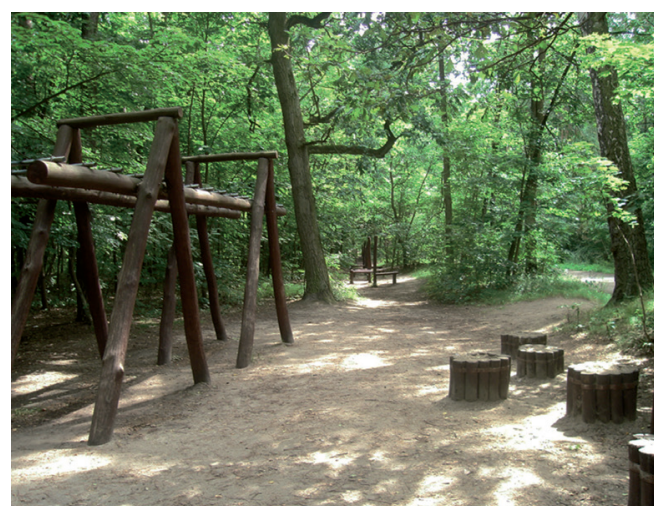

Photo: Wasilewski M. 2009

Fig. 6. Playground in Las Bielański nature reserve in Warsaw

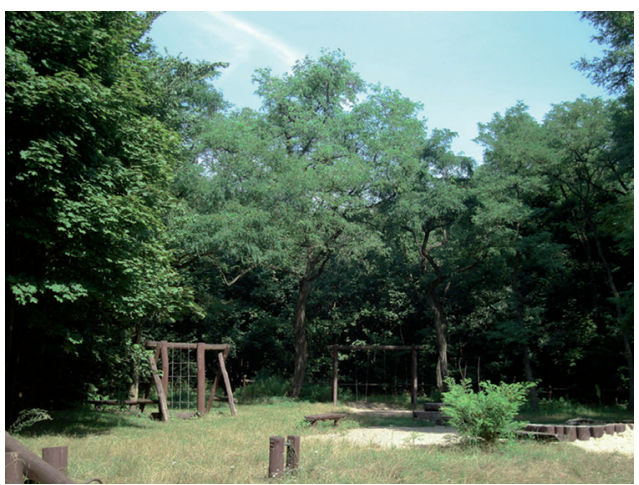

Photo: Wasilewski M. 2010

Fig. 7. Picnic tables and rain shelters in Las Bielański nature reserve in Warsaw

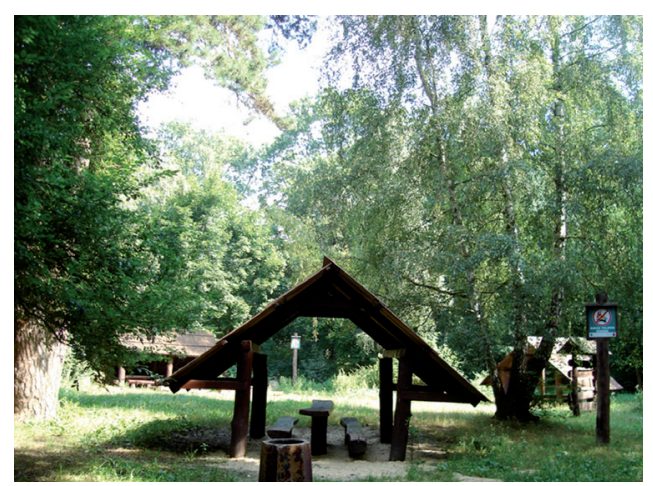

Photo: Wasilewski M. 2010
Within the mentioned group of 45 reserves, educational natural trails were designated in 12.15 of the investigated protected sites provide opportunities for cycling (about 32\% of all the legally accessible reserves). In the case of 6 nature reserves, car access - in certain indicated areas - is allowed. In Bór na Czerwonem nature reserve (in Nowy Targ) only cars with disabled people are allowed. In Las Lipowy Obrożyska (in Muszyna) a road is open only for forest maintenance, whereas in Karczówka a road leads to a private property. In the remaining 3 reserves: Dybanka (in Gostynin), Kacze Łęgi (in Gdynia) and Lisia Góra (in Rzeszów) car traffic on selected roads is allowed without particular restrictions.

There are also singular cases of reserves where other forms of activities are allowed, e.g. bonfires (2 reserves), camping (2), swimming (2), skiing (1), horse riding (1), fishing (1), dog walking (1), mushroom and berry collecting (1). Some nature reserves are equipped with playgrounds, sport and fitness devices. An outdoor gym is arranged in Las Kabacki im. Stefana Starzyńskiego in Warsaw, for example (Fig. 5). In this reserve, as well as in Las Bielański (Warsaw) places for children were arranged (Fig. 6). Moreover, in many reserves, other various tourist facilities can also be found, such as picnic tables, rain shelters (Fig. 7), wooden platforms or viewing points. Such elements are usually not mentioned or described in the official documents. 


\section{Protection versus recreation}

Some correlation can be found between legal recreational use and the number of protection objectives. In general, the more protection objectives a nature reserves has, the higher the probability that it is accessible to visitors (Fig. 8). The only exceptions are nature reserves with 5 objectives - only 1 of them is open to visitors so far. It should be mentioned, however, that this number would have been higher if the management plan for the Nad Białką nature reserve (located in Głuchołazy) which allowed touristic movement, had not been changed in 2016. Another reserve from this group - Przełomy pod Książem koło Wałbrzycha, although equipped with many touristic facilities, is still missing an ordinance allowing access for visitors. Among the other groups of reserves, divided according to the number of protection objectives, the smallest percentage of accessible reserves $-32.1 \%$ was identified for the areas with 1 objective. Within the group with 2 objectives, 35.9\% are publicly accessible. In the groups with 3 or 4 protection objectives, the share of reserves open to the public is higher and constitutes $55.6 \%$ and $53.8 \%$ respectively. $83.3 \%$ of the reserves with 6 objectives are open for recreational use. Karczówka in Kielce, with its 7 protection objectives (the only example of such a reserve), is also formally accessible to visitors.

\section{Scientific and educational values}

According to the Nature Protection Act 2004, both research in a nature reserve and its educational use have to be approved by the Regional Director for Environmental Protection. This regional authority decides whether scientific activities can be allowed, depending on the protected ecosystems and types of research requested. Activities for educational purposes can, in general, take place in all reserves that are legally accessible to visitors. In 68 (61.3\%)

Fig. 8. Share of nature reserves legally accessible in total number of investigated reserves (111) in relation to number of protection objectives (number of nature reserves is shown in brackets)

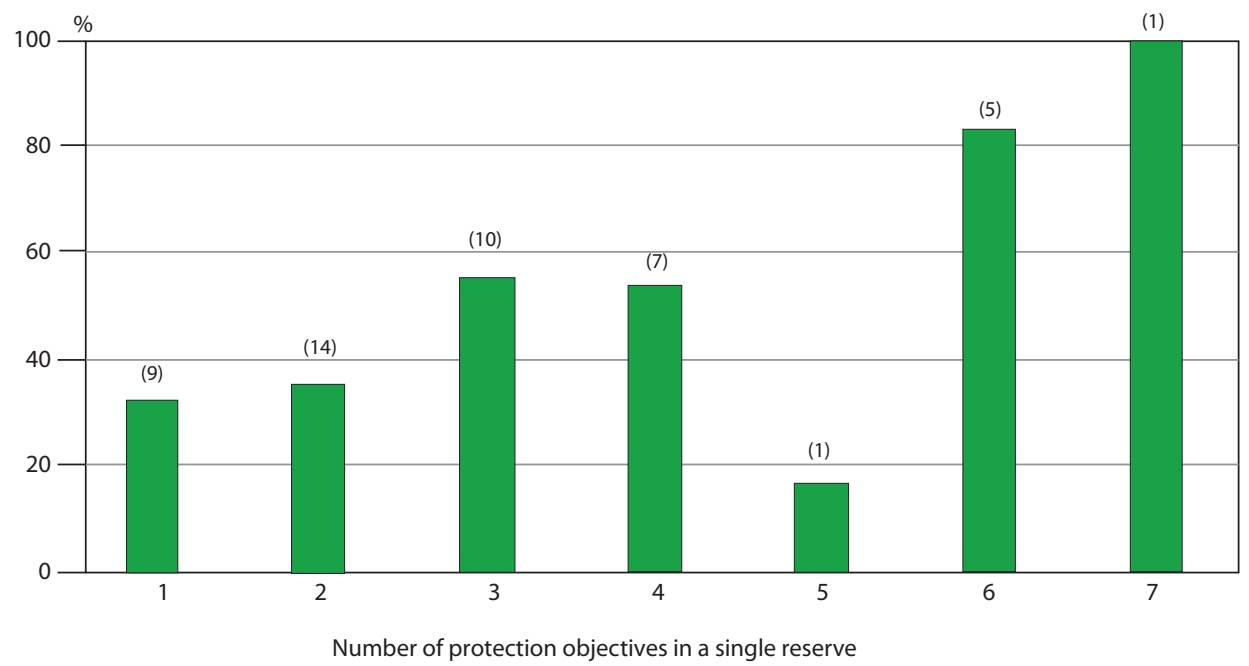


of the investigated nature reserves, official documents emphasized scientific values and in 60 $(54.1 \%)$ reserves - educational values as important aims of protection. In the documents that refer to the reserves established after $2004,{ }^{6}$ this is no longer the case. It seems that research and educational values are quite obvious characteristics of the reserves for the regional authorities for environmental protection, and specific regulations concerning them are being included in management plans.

\section{Social values}

Social values were emphasized in 8 of the investigated reserves $(7.2 \%)$ as an important aim of protection. In all of them the forest is one of the main protection objectives. 5 of these areas $(62.5 \%)$ are currently legally accessible to visitors. Within this group, Warsaw's nature reserves dominate: Las Bielański, Las Kabacki im. Stefana Starzyńskiego and Olszynka Grochowska. The first two play an important role for city inhabitants, especially for local residents of the numerous neighboring housing estates. People have been using these areas for years as places for leisure and recreation, social interactions or as spots where various events were organized. Although the introduction of a protection regime, in the form of a nature reserve, limited this use to some extent, people still treat these places as important in terms of social values. Olszynka Grochowska, which protects a forest located on the site of a historical battle also serves important social purposes because of its location within a densely inhabited area with an insufficient number of public green spaces.

\section{Management problems}

Among all nature reserves in Poland, the ones located in cities constitute about $10.5 \%{ }^{7}$ The main reasons for the popularity of these areas among residents and tourists is their high natural value, good accessibility - close to single and multi-family houses, usually with public transportation available - and sometimes also a shortage of other green spaces in cities. Many urban nature reserves are former historical parks or public recreational forests. Some others were established on old industrial areas, e.g. geological reserves in Kielce. For years people have associated these areas with leisure and recreation opportunities, which is often the reason for the current high human pressure. The establishment of nature protection forms has not significantly changed the practical use of these areas. As the research has shown, most urban nature reserves protect forests, which are usually willingly used by residents for recreational purposes and are fairly resistant to human pressure. The majority of reserves, however, are characterized by more than 1 protection objective.

\footnotetext{
${ }^{6}$ In 2004 the new Nature Protection Act was introduced. A year later (2005) the next 2 important documents were published: a decree about management plans (Rozporzadzenie Ministra Środowiska z dn. 12 maja 2005 r. w sprawie sporządzania projektu planu ochrony dla parku narodowego, rezerwatu przyrody i parku krajobrazowego, dokonywania zmian w tym planie oraz ochrony zasobów, tworów i składników przyrody) and a decree about categories, types and subtypes of nature reserves (Rozporządzenie Ministra Środowiska z dn. 30 marca 2005 r. w sprawie rodzajów, typów i podtypów rezerwatów przyrody).

7157 out of 1490 nature reserves [GUS, 2016] are located in cities. 111 are situated entirely within city borders.
} 
To the most popular natural elements, besides forests, belong flora, features of geological interests and the landscape. A high number of objectives may also be related to the designation process, where a combination of many values gives bigger incentives for protection, which is particularly important in urban landscapes, where competition for land is intense. This diversification makes protected areas also more attractive for visitors which, on the other hand, may lead to many conflicts between the protection of natural values and serving social purposes.

The main document that regulates (or should regulate) these issues is a management plan. Although it is obligatory, most urban nature reserves $(68,5 \%$ of those analyzed). still do not have such a document. The other official documents that regulate accessibility to the reserves are also missing (regional ordinances regarding this issue). According to the gathered data, less than half of the investigated reserves (only $42.4 \%$ ) are officially open to visitors and recreational use. It was noticed, however, that this share is higher (almost 55\%) among the reserves protecting more than 2 features. This can be a result of their higher leisure attractiveness for visitors and therefore stronger social pressure and expectations.

Another problematic issue is the system of intricate legal provisions which have created possibilities for different interpretations of the law. Regulations concerning access to the reserves and terms of their recreational use have been included for years in management plans. However, according to a recent statement by the Ministry of Environment and later also the General Directorate for Environmental Protection, such regulations have to be introduced by separate ordinances. Currently, the majority of the reserves still do not have these documents prepared, which is one of the main reasons why they are still not legally accessible. In practice, most of the reserves are frequently visited by people. Most of them offer walking paths and some basic tourist equipment such as benches and tables. In some places educational trails have been arranged. In the reserves located in the vicinity of highly populated areas places for recreation such as outdoor gyms, playgrounds or picnic spaces were set up. People seek for various forms of recreation and natural areas are gradually gaining popularity. It is therefore extremely important to regulate the issue of their accessibility, recreational and educational use as soon as possible.

\section{Conclusions}

1. Nature reserves in Polish towns and cities could be considered to be an essential element of natural and sometimes cultural heritage.

2. Formally established protection objectives are fairly diversified, however forested habitats predominate.

3. Protection objectives are often not precisely formulated which entails possible management problems regarding the reserves' recreational use.

4. It should be noted that recreation is not considered as a justification for setting up nature reserves. Only protection objectives are taken into account. 
5. The complicated and unclear formal situation of many of the analyzed reserves (e.g. a lack of properly issued formal documents) creates management problems, particularly in terms of the reserves' accessibility and recreational use.

6. In theory, the current legal regulations allow for rules regarding recreational use to be established and the necessary facilities to be set up, but in practice this issue has turned out to have been overlooked in many cases.

7. It seems that nature reserves located in towns and cities require more attention, otherwise some of them will lose their values. The concept of the urban nature reserve may be considered as a solution. However, the 'urban' classification should depend rather on the spatial context and surroundings of the reserves than administrative boundaries of towns and cities.

\section{Bibliography:}

Ahern, J., 2007, Green Infrastructure for Cities: the Spatial Dimension, (in:) V. Novotny, P. Brown (eds.), Cities of the Future: Towards Integrated Sustainable Water and Landscape Management, London: IWA Publishing, pp. 267-283.

Bistuła-Prószyński G., 2003, Turystyka w rezerwatach miasta stołecznego Warszawy - zagrożenia, sposoby eliminacji niekontrolowanego ruchu turystycznego, konflikty społeczne, (in:) Jaka turystyka w rezerwatach przyrody, Materiały z V Krajowej Konferencji „Ochrona przyrody a turystyka”, Wyd. Uniwersytet Rzeszowski, Rzeszów, pp. 63-72.

Główny Urząd Statystyczny (GUS), 2016, Ochrona środowiska. Informacje i opracowania statystyczne, Warszawa.

Grabowska E., 2014, Czy rezerwaty pomagaja chronić przyrode w mieście?, (in:) M. Kosmala (ed.), Kierunki zmian terenów zieleni w miastach, Polskie Zrzeszenie Inżynierów i Techników Sanitarnych Oddział Toruń, Toruń, pp. 345-353.

Giedych R., Szulczewska B., Dobson S., Halounova L., Doygun H., 2014, Green infrastructure as a tool of urban areas sustainable development, (in:) R. Davson, A. Wyckmans, O. Heidrich, J. Köhler, S. Dobson, E. Feliu (eds.), Understanding Cities: Advances in Integrated Assessment of Urban Sustainability, Centre for Earth System Engineering Research, Newcastle, pp. 94-108.

IUCN, The International Union for Conservation of Nature, Category IV: Habitat/ Species Management Area, https://www.iucn.org/theme/protected-areas/about/protected-areascategories/category-iv-habitatspecies-management-area [access: 02.06.2017]. 
Malinowska E., Szumacher I., 2013, Problemy funkcjonowania rezerwatów w mieście. „Problemy Ekologii Krajobrazu", Rekreacja w krajobrazach o wysokim potencjale, vol. XXXIV, pp. 175-180.

Mell, I.C., Henneberry, J., Hehl-Lange S., \& Keskin B., 2013, Promoting urban greening: Valuing the development of green infrastructure investments in the urban core of Manchester, UK, "Urban Forestry \& Urban Greening", 12, pp. 296-306.

Radziejowski J., 2011, Obszary chronionej przyrody. Historia, stan obecny, wyzwania przyszłości, Warszawa.

Rozporządzenie Ministra Środowiska z dn. 30 marca 2005 roku w sprawie rodzajów, typów i podtypów rezerwatów przyrody, Dziennik Ustaw 2005 Nr 60, poz. 533.

Szulczewska B., 2009, Plan zielonej infrastruktury: nowa moda czy rzeczywista potrzeba?, (in:) T. Markowski i D. Drzazga (eds.), System przyrodniczy w zarządzaniu rozwojem obszarów metropolitalnych, Studia KPZK PAN T. CXXIII, Warszawa, pp. 89- 96.

Szulczewska B., 2002, Problemy ochrony przyrody, (in:) Gzell S. (ed.), Krajobraz Architektoniczny Warszawy końca XX wieku, Towarzystwo Urbanistów Polskich Oddział Warszawski, Warszawa, pp. 259-276.

Ustawa o ochronie przyrody, 2004, Dziennik Ustaw 2004 Nr 92, poz. 880, z późn. zm. 


\section{PROTECTION OBJECTIVES IN POLISH URBAN NATURE RESERVES AS A CHALLENGE FOR THEIR... \\ Maciej Wasilewski, Barbara Szulczewska}

\section{Zróżnicowane cele ochrony rezerwatów przyrody w polskich miastach jako problem zarządzania}

\section{STRESZCZENIE}

W strukturze przestrzennej polskich miast występuje 157 rezerwatów. Były one powoływane w różnym czasie, często z powodów nieco odmiennych, niż w przypadku rezerwatów ustanawianych poza obszarami miast. Z powodu swego usytuowania, rezerwaty $\mathrm{w}$ miastach są $\mathrm{w}$ znacznym stopniu wykorzystywane podobnie jak inne tereny zieleni. Stąd też celem artykułu jest ustalenie głównych celów ochrony tych rezerwatów oraz relacji celów ochrony do nieuniknionej funkcji rekreacyjnej badanych rezerwatów, a następnie - stwierdzenie, w jakim stopniu generuje to problemy zarządzania. Cele ochrony oraz formalne zasady udostępniania rezerwatów zostały określone na podstawie analizy 111 zarządzeń powołujących rezerwaty (analizą objęto jedynie te rezerwaty, które w całości są usytuowane w granicach miast), 35 planów ochrony oraz 48 planów zadań ochronnych). W wyniku przeprowadzonych badań ustalono, że: skomplikowana i niejednoznaczna sytuacja formalno- prawna powoduje istotne problemy udostępniania rezerwatów dla mieszkańców miast. Ustalono, że choć - teoretycznie - obecne regulacje prawne pozwalają na określenie zasad wprowadzania funkcji i urządzeń rekreacyjnych, to - w praktyce - możliwości te są słabo wykorzystywane. Wydaje się zatem, że rezerwaty przyrody zlokalizowane w miastach wymagają szczególnej uwagi. Bez specjalnych rozwiązań, w wielu przypadkach, ich walory przyrodnicze mogą zostać bezpowrotnie utracone. Być może rozwiązaniem tego problemu byłaby koncepcja "rezerwatu miejskiego".

Maciej Wasilewski - PhD student at the Department of Landscape Architecture (Warsaw University of Life Sciences). His main research focus is on nature protection areas in cities, especially on urban nature reserves.

Contact to the author: maciej_wasilewski@sggw.pl.

doktorant w katedrze Architektury Krajobrazu (Szkoła Główna Gospodarstwa Wiejskiego w Warszawie). Specjalizuje się w zagadnieniach zwiq̨zanych z obszarami chronionej przyrody w miastach, w szczególności rezerwatami przyrody na terenach zurbanizowanych.Kontakt do autora: maciej_wasilewski@sggw.pl. 